\title{
Contraceptive behavior of Portuguese higher education students
}

\author{
Comportamentos contraceptivos de estudantes portugueses do ensino superior \\ Comportamiento anticonceptivo de estudiantes portugueses en la educación superior
}

\begin{abstract}
Maria José de Oliveira Santos', Elisabete Maria Soares Ferreira", Manuela Maria da Conceição Ferreira'"I
\author{
'Universidade do Porto, Abel Salazar Institute of Science Biomédicas. Porto, Portugal
"Universidade do Porto, Faculty of Psychology and Education Sciences. Porto, Portugal. \\ 'Universidade do Porto, Abel Salazar Institute of Science Biomédicas. Porto, Portugal
"Universidade do Porto, Faculty of Psychology and Education Sciences. Porto, Portugal. \\ I'I Instituto Politécnico de Viseu, Viseu College of Health. Viseu, Portugal.
}

How to cite this article:

Santos MJO, Ferreira EMS, Ferreira MMC. Contraceptive behavior of Portuguese higher education students. Rev Bras Enferm [Internet]. 2018; 71(Suppl 4):1706-13. [Thematic issue: Education and teaching in Nursing] DOI: http://dx.doi.org/10.1590/0034-7167-2017-0623

Submission: 09-30-2017 Approval: 12-27-2017

\begin{abstract}
Objective: To characterize the contraceptive practices of higher education students and to identify factors that contribute to the use of different contraceptive methods. Method: A cross-sectional, descriptive correlational study was carried out with a sample of 1946 students, with a mean age of 21 years $(20.74 \pm 2.32)$, who attended courses at a University in the North of Portugal. Results: Of the factors studied, the female gender, younger ages, previous behavior of condom use, knowledge about contraception, attitude and self-efficacy for condom use were associated with safer contraceptive choices. Conclusion: Investing in sexual education for young people is an important public health strategy that can empower youth to make more appropriate choices and improve adherence to contraceptive methods, reducing the risk of unintended pregnancies and sexually transmitted diseases.
\end{abstract}

Descriptors: Contraception; Nursing Care; Students; Condoms; Reproductive Health.

\section{RESUMO}

Objetivo: Caracterizar as práticas contraceptivas de estudantes do ensino superior e identificar fatores que contribuem para a utilização dos diferentes métodos contraceptivos. Método: Foi realizado um estudo transversal, descritivo-correlacional, numa amostra de 1946 estudantes, com idade média de 21 anos $(20,74 \pm 2,32)$, que frequentavam cursos de uma Universidade do norte de Portugal. Resultados: Dos fatores estudados, o gênero feminino, as idades mais novas, o comportamento anterior de usar o preservativo, o conhecimento sobre contracepção, a atitude e autoeficácia para usar o preservativo estiveram associados a escolhas contraceptivas mais seguras. Conclusão: Investir na educação sexual dos jovens adultos é uma importante estratégia de saúde pública, que pode potenciar escolhas mais adequadas e melhorar adesão à contracepção, diminuindo o risco de gravidez indesejada e de infeções sexualmente transmissíveis.

Descritores: Métodos Contraceptivos; Cuidados de Enfermagem; Estudantes; Preservativo; Saúde Reprodutiva.

\section{RESUMEN}

Objetivo: Caracterizar las prácticas anticonceptivas de los estudiantes de educación superior e identificar los factores que contribuyen a la utilización de diferentes métodos anticonceptivos. Método: Se trata de un estudio transversal, descriptivo correlacional, en una muestra de 1.946 estudiantes, con edad promedio de 21 años $(20,74 \pm 2,32)$, frecuentadores de cursos de una Universidad del norte de Portugal. Resultados: De los factores estudiados, el género femenino, la edad menor, el comportamiento anterior de uso del preservativo, el conocimiento sobre anticoncepción, la actitud y la auto-eficiencia para usar el preservativo estaban asociados a las alternativas anticonceptivas más seguras. Conclusión: Invertir en la educación sexual de los jóvenes adultos es una estrategia de salud pública importante, que puede potenciar elecciones más adecuadas y mejorar la adhesión a la anticoncepción, disminuyendo el riesgo de embarazos indeseados y de infecciones sexualmente transmisibles. Descriptores: Métodos Anticonceptivos; Cuidados de Enfermería; Estudiantes; Preservativo; Salud Reproductiva. 


\section{INTRODUCTION}

Young people are considered a priority group for sexual and reproductive health $(\mathrm{SRH})$, with strategies focused on the prevention of sexually transmitted diseases (STDs) and unintended pregnancies ${ }^{(1-3)}$. Health professionals, particularly nurses, have a key role in contraceptive education for young people, not only to provide them with the ability to choose contraceptive methods, but also to emphasize the importance of using barrier methods as protection against STDs and to recommend regular surveillance of $\mathrm{SRH}^{(4-5)}$.

The effective use of contraceptive methods depends on multiple factors related to the complexity of sexual behavior, which should be considered when designing programs to promote sexual and reproductive health for young people. In this sense, some researchers emphasize the importance of studies that seek to understand the influence of psychosocial and behavioral factors on the contraceptive practices of young adults. On that subject, some aspects can be emphasized: the importance of the perception of (in)vulnerability to STDs ${ }^{(6)}$; (in)ability to plan sexual activity given the spontaneous nature of sexual intercourse in this age group ${ }^{(7)}$; self-efficacy for consistent condom use ${ }^{(1,8)}$; difficulties in the communication with the sexual partner, parents and health professionals about contraception ${ }^{(9)}$; and the type of love relationship ${ }^{(10-11)}$. In addition, in the university context, other sexual behaviors identified constitute an inadequate use of contraceptive methods. Some behaviors observed are considered almost ordinary in the context of nightlife and college parties ${ }^{(12-13)}$, such as the practice of unprotected sex with occasional partners and even in more stable relationships ${ }^{(14-15)}$, and the use of psychoactive substances, such as alcohol and drugs, associated with sexual intercourse. The consumption of these substances may lead to less effective contraception, either due to misuse or to inability to negotiate the use of condom with the sexual partner ${ }^{(16)}$.

Universal access to consultations and contraceptive methods is the preferred way of reducing unintended pregnancies and STDs ${ }^{(4)}$. However, there are still barriers and asymmetries in access to SRH care, especially among young people, as documented in a national study on contraceptive practices of Portuguese women ${ }^{(17)}$. This study found that $50 \%$ of women between 20 and 29 with active sex life and using contraception methods did not attend the family planning consultation in the previous year. Lack of information, fear about confidentiality, fear of potential side effects, or even lack of knowledge about contraceptive methods are some of the factors that contribute to postponing the search for contraceptive information ${ }^{(9,18)}$. Health services and nursing professionals should provide contraceptive education for young people, considering that several studies have shown that counseling improves contraceptive use and decreases contraceptive discontinuation ${ }^{(3)}$.

The consequences of sexual risk behavior among young people, including unintended pregnancies and STDs, are a public health problem ${ }^{(5-6)}$. Thus, it is essential to understand the factors that may influence use of contraceptives, in order to design programs and plan strategies to promote a more adequate and safe use of contraceptive methods to this population.

\section{OBJECTIVE}

To characterize the contraceptive practices of higher education students considering gender issues, and to identify factors that contribute to the use of different contraceptive methods.

\section{METHOD}

\section{Ethical aspects}

During data collection, the deontological-ethical principles established in the Declaration of Helsinki were followed. The study was authorized by the Research Ethics Committee of the University where it was conducted.

\section{Study design, setting and period of study}

A cross-sectional, descriptive correlational study was carried out with a sample of students from a University in the north of Portugal during the academic year 2012/2013.

\section{Population or sample: inclusion and exclusion criteria}

The sampling technique used was Cluster sampling, with the classes as group or sample unit. The sample consisted of 1946 students, 1246 female (64\%) and 700 male (36\%). Inclusion criteria were: students aged between 18 and 29 years old, attending the classes selected from teaching license undergraduate courses of the five Schools that compose the University.

\section{Study Protocol}

Data was collected through a self-completion questionnaire that was applied in the end of a class to all students who voluntarily agreed to participate in the study. Agreement was obtained after informing the students about the research objectives and ensuring their anonymity

The questionnaire collected socio-demographic data (gender, age, place of birth, level of education of parents, monthly family income), academic data (scientific area of studies), sexual and contraceptive behavior (used a condom at first sexual encounter, had sexual intercourse in the last 12 months, use of contraceptive method, which contraceptive was used, sources of contraceptive information, place of purchase, and emergency contraception practices). Data on the cognitive and psychosocial factors that, according to the literature, may influence contraceptive practices were also collected. Knowledge about contraception was evaluated by the SRH Knowledge Inventory (ICSRH), consisting of 44 items developed specifically for the study. This instrument presents four dimensions: information related to physiology and reproduction, contraception methods, prevention of risks associated with STDs and SRH surveillance. All items had three options ("true", "false" and "I don't know"). The correct answers were coded as one and the incorrect answers or "I don't know" as zero. The total score of the ICSRH ranges from 0 to 44 points, and the higher the score the higher the knowledge about SRH. The reliability of the ICSRH was evaluated by the Kuder-Richardson coefficient (KR20=0.78), which confirmed the adequate internal consistency of the instrument. In the present study, only the dimension of knowledge related to contraception was used, which consisted of 16 questions with a total score varying between $0-16$ points and KR20 $=0.77$. 
SRH attitude was assessed using a 20-item scale, constructed and validated in the present study. The scale consists of five dimensions: responsible sexuality, preventive attitudes, attitudes regarding STDs, attitudes regarding condoms and hedonism. The questions were evaluated on a Likert scale with seven response options ( 1 - "totally disagree" and 7 - "fully agree"). The total score ranged from 20 to 140 points and highest scores indicate more positive attitudes. The scale showed good internal consistency (Cronbach's alpha $=0.82$ ).

Self-efficacy for condom use was evaluated by the reduced version of the Condom Use Self-Efficacy Scale (CUSES) ${ }^{(19)}$. The scale is composed of 15 items, evaluated in a Likert scale with five options ( 0 - "totally disagree" to 4 - "totally agree"). The total score ranges from 0 to 60 points, and higher scores indicate a greater self-efficacy for condom use. The scale has a multidimensional structure composed of four factors (mechanics, partner disapproval, assertive and intoxicants) and has demonstrated good psychometric properties of reliability and validity in several researches. In the present study, we used the translated and validated Portuguese version (CUSES-R) ${ }^{(20)}$, which maintained a factorial structure similar to the original scale. CUSES-R had a good Cronbach's alpha value $(\alpha=0.86)$, similar to the original scale ( $\alpha=0.85)$.

The perception of social support was evaluated by the Social Support Satisfaction Scale (ESSS) ${ }^{(21)}$, which evaluates the perceived social support received from friends, family and community. The scale is composed of 15 items, distributed in four dimensions: satisfaction with friends, intimacy, satisfaction with family and social activities. The questions are evaluated on a Likert scale with five options (1- "totally agree" to 5 - "totally disagree"). The total score varies from 15 to 75 points and higher scores correspond to greater satisfaction with social support. After the ESSS validation process in the sample of the present study, the scale was constituted by 12 items distributed in four dimensions, the same ones proposed by the author. Internal consistency values were adequate $(\alpha=0.814)$ and similar to those found by the authors $(\alpha=0.85)$.

\section{Analysis of results and statistics}

Statistical analysis was performed with the Statistical Package for the Social Sciences (SPSS, Inc, Chicago, IL, USA), version 22.0. Descriptive and inferential statistics were used for data analysis. The association between socio-demographic characteristics and contraceptive choices was analyzed using the chi-square test $\left(\mathbf{X}^{2}\right)$, with residual analysis to identify significant values. The relationship between cognitive, psychosocial factors and contraceptive choices was established through analysis of variance (Anova). Location of mean differences were performed using Tukey's test. In all inferential statistics, $\mathrm{p}$-value significance was set as $<0.05$. The variables related to the use of condoms were adjusted considering the control question to assess if the student consistently used the condom. The student was considered as one who uses condoms only when he indicated in the control question to use it always.

\section{RESULTS}

A total of 1946 students participated in the study, 1246 female $(64 \%)$ and 700 male $(36 \%)$, with a mean age of 21 years $(20.74$ $\pm 2.32)$. Most of them are single $(97.6 \%)$, from the city $(40 \%)$, come from low income families $(57 \% \leq 2$ minimum wages) with low level of education (54.5\% of mothers and $61.6 \%$ of fathers only had basic education) and with common professions.

The main characteristics of the contraceptive practices of higher education students are presented in Table 1. The target population of this study was 1946 students, of which $76.9 \%$ indicated they had had sexual intercourse in the last 12 months. The concern of young women with contraception becomes clear when looking at the proportion of girls who reported not using any contraceptive method $(7.2 \%)$, which was much lower than the proportion of boys $(32.6 \%)$. When information on the use of contraceptive methods was cross-referenced with the control question to assess the consistent use of condoms, it was possible to observe that about half of the students $(49.8 \%)$ who reported using condoms alone or in combination with the pill did not use it consistently and were therefore considered non-users. The girls preferred the hormonal methods (52.9\%) and the boys the condom $(32.1 \%)$. Almost all of the students who reported using the hormonal method used the pill. Non-user dependent contraceptive methods (vaginal ring, contraceptive patch or contraceptive injection) were used by only about $1 \%$ of the students. One missed pill was reported by $45.1 \%$ of the students and two or more by $27.8 \%$. In case of missed pill, $83.4 \%$ of the students took it in the next 24 hours, $14.2 \%$ used a condom and $2.3 \%$ used emergency contraception (EC). The sources of information on contraception are diverse, with a very clear difference between genders. Girls favor formal contexts, such as health professionals, while boys resort to informal contexts such as school, friends and the internet. Regarding the location and acquisition of contraceptives, young women prefer to obtain them in pharmacies $(60.2 \%)$ and in the health center $(42.5 \%)$, whereas boys, although they also prefer the pharmacy, they buy contraceptives more often in the supermarket (44.9\%). The use of EC is reported by $23.8 \%$ of the students and is similar $(p=0.293)$ in both genders. Nevertheless, EC recurrence is different between genders $(p=0.009)$, with a higher proportion of boys (15.9\%) reporting the use of EC by the female partner in three or more occasions. Differences between genders $(p=0.002)$ were also observed regarding the arguments presented for the use of this method, since the girls reported they used EC because of failure of the regular method (87.9\%) more frequently than boys $(73.1 \%)$, and a significant percentage of boys reported using EC due to unprotected sex (23.7\%).

The influence of individual and environmental factors on the choice of contraception considering gender is presented in Table 2. Older students tended to value hormonal contraception more, apparently as a replacement for the condom, since the use of this method decreased with age, particularly among younger boys ( $\leq 19$ years) and those between 20 and 24 years old.

For girls, hormonal contraception was the main method of choice in all age groups. The environment in which students grew up (urban or rural) and family income did not influence contraceptive choices ( $p \geq 0.05$ ). The use of condom in the first sexual encounter reflected in its current use. The use of condom in this past event is associated with current regular use of condoms by $26.7 \%$ of the total number of students, while unprotected sex in the first sexual encounter is associated with $6.4 \%$ of current use, with statistically significant differences $(p<0.001)$. Students having sex in the context of a stable relationship have greater adherence to hormonal 
contraception and concomitantly stop using condoms, especially boys. Since stable relationship and more advanced age are factors associated with the abandonment of the condom, it was assumed that these were the same individuals, that is, the older ones were involved in a relationship. However, when this association was tested, it was not significant ( $\mathrm{X} 2=0.009 ; \mathrm{p}=0.995)$. The area of study only had repercussions on the contraceptive choices of the boys: among the high percentage of students who did not use contraception $(32.6 \%)$, the proportion of those attending courses in the area of life science or health was significantly lower $(p=0.025)$ than those from other areas $(38.4 \%)$.

In order to evaluate the influence of cognitive and psychosocial aspects on the students' contraceptive choices, several instruments were applied to collect information on contraceptive knowledge, attitude towards SRH, self-efficacy for condom use for and satisfaction with social support (Table 3). Knowledge about contraception influenced students' choices. Among girls, those who did not use contraception were those who had less knowledge, which was significantly different $(p<0.05)$ from those who used the dual protection pill/condom. In the group of boys, curiously, those with less knowledge are not those who do not use contraception, but those who use only condom, distinguishing themselves from those who have sex with dual protection.

SRH attitude follows a pattern similar to that observed for knowledge: the most unfavorable SRH attitude is observed in students who did not use contraception and the most favorable in those using dual protection. The condom use self-efficacy scale confirms the trend observed in the preceding variables. Students' condom use self-efficacy is high. Students who do not use contraception had less self-efficacy for condom use. These differences did not have statistical significance in the males' group, since even those who did not use contraception had high scores. Among young women, those who did not use contraception had a significantly lower condom use selfefficacy than those who did, regardless of the method chosen. Satisfaction with social support showed no influence on the contraceptive choices made by students.

Table 1 - Characterization of contraceptive practices of higher education students

\begin{tabular}{|c|c|c|c|c|}
\hline \multirow[b]{2}{*}{ Variables } & \multicolumn{2}{|c|}{ Gender } & \multirow[b]{2}{*}{$p$} & \multirow{2}{*}{$\begin{array}{c}\text { Total } \\
(n=1946)\end{array}$} \\
\hline & $\begin{array}{c}\text { Female } \\
(n=1246)\end{array}$ & $\begin{array}{c}\text { Male } \\
(n=700)\end{array}$ & & \\
\hline Had sexual intercourse in the last 12 months & $923(74.1)$ & $573(81.9)$ & $<0.001$ & $1496(76.9)$ \\
\hline $\begin{array}{l}\text { Contraceptive method used } \\
\text { None } \\
\text { Condom } \\
\text { Hormonal } \\
\text { Dual protection }\end{array}$ & $\begin{array}{c}67(7.2) \\
143(15.5) \\
489(52.9) \\
226(24.4)\end{array}$ & $\begin{array}{c}186(32.6) \\
183(32.1) \\
164(28.8) \\
37(6.5)\end{array}$ & $<0.001$ & $\begin{array}{l}253(16.9) \\
326(21.8) \\
653(43.7) \\
263(17.6)\end{array}$ \\
\hline $\begin{array}{l}\text { Source of information on contraception }{ }^{\Psi} \\
\text { Nurse } \\
\text { Doctor } \\
\text { Pharmacy } \\
\text { Mom } \\
\text { Dad } \\
\text { Friends } \\
\text { Teacher } \\
\text { Internet }\end{array}$ & $\begin{aligned} 330 & (35.8) \\
596 & (64.6) \\
74 & (8.0) \\
267 & (28.9) \\
44 & (4.8) \\
174 & (18.9) \\
163 & (17.7) \\
182 & (19.7)\end{aligned}$ & $\begin{array}{c}90(15.7) \\
157(27.4) \\
101(17.6) \\
163(28.4) \\
154(26.9) \\
230(40.1) \\
227(39.6) \\
257(44.9)\end{array}$ & $\begin{array}{c}<0.001 \\
<0.001 \\
<0.001 \\
0.842 \\
<\mathbf{0 . 0 0 1} \\
<\mathbf{0 . 0 0 1} \\
<\mathbf{0 . 0 0 1} \\
<\mathbf{0 . 0 0 1}\end{array}$ & $\begin{array}{c}420(28.11) \\
753(50.3) \\
175(11.7) \\
430(28.7) \\
198(13.2 \\
404(27.0) \\
390(26.1) \\
439(29.3)\end{array}$ \\
\hline $\begin{array}{l}\text { Where contraceptives were acquired }{ }^{\Psi} \\
\text { Pharmacy } \\
\text { Health center } \\
\text { Supermarket; stores in general }\end{array}$ & $\begin{array}{l}556(60.2) \\
392(42.5) \\
130(14.1)\end{array}$ & $\begin{array}{l}356(62.1) \\
101(17.6) \\
257(44.9)\end{array}$ & $\begin{array}{l}0.500 \\
<\mathbf{0 . 0 0 1} \\
<\mathbf{0 . 0 0 1}\end{array}$ & $\begin{array}{l}912(61.0) \\
493(33.0) \\
387(25.9)\end{array}$ \\
\hline $\begin{array}{l}\text { Used EC in the past } \\
\text { How many times } \\
\text { One } \\
\text { Two } \\
\text { Three or more }\end{array}$ & $\begin{array}{l}306(24.6) \\
214(69.7) \\
73(23.8) \\
20(6.5)\end{array}$ & $\begin{array}{l}157(22.5) \\
98(62.8) \\
34(21.8) \\
24(15.4)\end{array}$ & $\begin{array}{l}0.293 \\
0.009\end{array}$ & $\begin{array}{l}463(23.8) \\
312(67.4) \\
107(23.1) \\
44(9.5)\end{array}$ \\
\hline $\begin{array}{l}\text { Reason for EC } \\
\text { Failure of regular method } \\
\text { Absence of contraception }\end{array}$ & $\begin{array}{c}270(87.9) \\
37(12.1)\end{array}$ & $\begin{array}{c}119(76.3) \\
37(23.7)\end{array}$ & 0.002 & $\begin{array}{c}389(84.0) \\
74(16.0)\end{array}$ \\
\hline $\begin{array}{l}\text { Received information when acquired the EC } \\
\text { Had an unintended pregnancy } \\
\text { (or his partner) } \\
\text { Used SRH services }\end{array}$ & $\begin{array}{l}229(74.6) \\
26(2.8) \\
379(30.4)\end{array}$ & $\begin{array}{l}121(77.6) \\
20(3.5) \\
53(7.6)\end{array}$ & $\begin{array}{l}0.482 \\
0.462 \\
<\mathbf{0 . 0 0 1}\end{array}$ & $\begin{array}{c}350(75.6) \\
46(3.1) \\
432(22.2)\end{array}$ \\
\hline
\end{tabular}

Note: ${ }^{\Psi}$ - Questions that allowed more than one answer. EC-Emergency Contraception. SRH - sexual and reproductive health 
Table 2 - Influence of environmental and individual factors on the contraceptive choices of higher education students

\begin{tabular}{|c|c|c|c|c|c|c|c|c|c|c|c|c|c|c|c|}
\hline \multirow[b]{2}{*}{$\begin{array}{l}\text { Individual and } \\
\text { Environmental Factors }\end{array}$} & \multicolumn{5}{|c|}{ Female } & \multicolumn{5}{|c|}{ Meal } & \multicolumn{5}{|c|}{ Total } \\
\hline & No. & Con. & Hor. & Dua. & $\underset{p}{\text { Qui }^{2}}$ & No. & Con. & Hor. & Dua. & $\underset{p}{\text { Qui }^{2}}$ & No. & Con. & Hor. & Dou. & $p$ \\
\hline \multicolumn{16}{|l|}{ Age } \\
\hline$\leq 19$ & 7.2 & 24.0 & 42.3 & 26.5 & 30.303 & 30.9 & 41.7 & 18.7 & 8.6 & 17.740 & 15.1 & 29.9 & 34.4 & 20.6 & \\
\hline $20-24$ & 7.2 & 11.8 & 56.7 & 24.2 & $<0.001$ & 31.7 & 28.09 & 32.8 & 6.7 & 0.007 & 16.5 & 18.2 & 47.7 & 17.6 & $<0.001$ \\
\hline$\geq 25$ & 7.7 & 11.5 & 65.4 & 15.4 & & 40.8 & 29.6 & 28.2 & 1.4 & & 26.8 & 22.0 & 43.9 & 7.3 & \\
\hline \multicolumn{16}{|l|}{ Place where grew up } \\
\hline Urban & 6.4 & 15.3 & 56.1 & 22.3 & 2.826 & 33.6 & 31.0 & 29.9 & 5.5 & 3.013 & 18.0 & 21.7 & 42.5 & 17.7 & \\
\hline Rural & 7.8 & 15.6 & 50.9 & 25.8 & 0.419 & 30.7 & 34.4 & 26.5 & 8.5 & 0.390 & 15.0 & 22.1 & 45.6 & 17.4 & 0.438 \\
\hline \multicolumn{16}{|l|}{ Family income } \\
\hline$<2 \mathrm{MW}$ & 7.6 & 16.1 & 52.0 & 24.3 & 1.655 & 34.2 & 33.8 & 25.2 & 6.8 & 4.803 & 16.6 & 22.1 & 42.9 & 18.3 & \\
\hline $2-4 \mathrm{MW}$ & 6.7 & 14.5 & 55.4 & 23.4 & 0.949 & 33.5 & 30.2 & 30.7 & 5.6 & 0.569 & 17.4 & 20.8 & 45.5 & 16.3 & 0.949 \\
\hline$>4 \mathrm{MW}$ & 6.9 & 147.7 & 50.9 & 27.6 & & 27.4 & 31.0 & 34.5 & 7.1 & & 17.0 & 22.7 & 42.8 & 17.5 & \\
\hline \multicolumn{16}{|l|}{$\begin{array}{l}\text { Used a condom } n \text { the } 1^{\text {st }} \\
\text { sexual encounter }\end{array}$} \\
\hline No & 7.1 & 2.6 & 56.4 & 33.8 & 54.135 & 29.5 & 16.8 & 46.3 & 7.4 & 2.951 & 13.0 & 6.4 & 53.7 & 26.9 & \\
\hline Yes & 7.3 & 20.6 & 51.4 & 20.6 & $<0.001$ & 33.3 & 35.2 & 25.3 & 6.3 & $<0.001$ & 18.2 & 26.7 & 40.5 & 14.6 & $<0.001$ \\
\hline \multicolumn{16}{|l|}{$\begin{array}{l}\text { Sexual relations in a stable } \\
\text { relationship }\end{array}$} \\
\hline No & 12.5 & 12.5 & 33.3 & 41.7 & 12.026 & 40.2 & 50.9 & 6.3 & 2.7 & 45.453 & 31.9 & 39.4 & 14.4 & 14.4 & \\
\hline Yes & 7.0 & 15.6 & 53.9 & 23.5 & 0.007 & 30.8 & 27.5 & 34.3 & 7.4 & $<0.001$ & 15.1 & 19.7 & 47.2 & 18.0 & $<0.001$ \\
\hline \multicolumn{16}{|l|}{ Scientific area of study } \\
\hline Life Sciences and Health & 6.2 & 16.1 & 51.6 & 26.1 & 5.563 & 28.9 & 31.2 & 32.7 & 7.2 & 9.326 & 14.5 & 21.6 & 44.7 & 19.3 & \\
\hline $\begin{array}{l}\text { Human and Social } \\
\text { Sciences and Technology }\end{array}$ & 9.2 & 14.2 & 55.4 & 21.2 & 0.135 & 38.4 & 33.5 & 22.8 & 5.4 & 0.025 & 21.3 & 22.2 & 41.9 & 14.6 & 0.002 \\
\hline
\end{tabular}

Note: No. None; Con. Condom; Hor. Hormonal; Dua. Dual Protection; MW - Minimum Wage (550 euros); The frequencies in bold correspond to standardized residual $\geq 1.96$, in absolute value.

Table 3 - Influence of cognitive and psychosocial factors on the contraceptive choices of higher education students

\begin{tabular}{|c|c|c|c|c|c|c|}
\hline Cognitive and psychosocial factors & Gender & None & Condom & Hormonal & Dual & $p$ \\
\hline $\begin{array}{l}\text { Knowledge about contraception } \\
\qquad(0-16)^{\Psi}\end{array}$ & $\begin{array}{c}\text { Moças } \\
\text { Rapazes } \\
\text { Total }\end{array}$ & $\begin{array}{c}8.49 \pm 2.53 a \\
7.37 \pm 2.81 \mathrm{ab} \\
7.67 \pm 2.78 \mathrm{a}\end{array}$ & $\begin{array}{l}8.66 \pm 2.20 \mathrm{a} \\
7.01 \pm 2.56 \mathrm{a} \\
7.74 \pm 2.54 \mathrm{a}\end{array}$ & $\begin{array}{c}9.05 \pm 1.98 \mathrm{ab} \\
7.67 \pm 2.32 \mathrm{ab} \\
8.71 \pm 2.15 \mathrm{~b}\end{array}$ & $\begin{array}{l}9.54 \pm 2.09 b \\
8.14 \pm 2.43 b \\
9.34 \pm 2.19 c\end{array}$ & $\begin{array}{c}<\mathbf{0 . 0 0 1} \\
0.029 \\
<\mathbf{0 . 0 0 1}\end{array}$ \\
\hline $\begin{array}{l}\text { SRH attitude } \\
\qquad(20-140)^{\Psi}\end{array}$ & $\begin{array}{c}\text { Moças } \\
\text { Rapazes } \\
\text { Total }\end{array}$ & $\begin{array}{l}119.09 \pm 12.17 a \\
110.38 \pm 16.22 a \\
112.68 \pm 15.71 a\end{array}$ & $\begin{array}{c}122.36 \pm 12.69 a b \\
112.44 \pm 16.60 a \\
116.79 \pm 15.78 b\end{array}$ & $\begin{array}{c}121.24 \pm 11.06 a b \\
112.63 \pm 14.68 a b \\
119.07 \pm 12.62 b\end{array}$ & $\begin{array}{l}124.28 \pm 10.88 b \\
118.51 \pm 14.74 b \\
123.47 \pm 11.64 c\end{array}$ & $\begin{array}{c}0.001 \\
0.037 \\
<\mathbf{0 . 0 0 1}\end{array}$ \\
\hline $\begin{array}{l}\text { Condom use self-efficacy } \\
\qquad(0-60)^{\Psi}\end{array}$ & $\begin{array}{c}\text { Moças } \\
\text { Rapazes } \\
\text { Total }\end{array}$ & $\begin{array}{c}44.24 \pm 9.43 a \\
47.40 \pm 9.59 \\
46.56 \pm 9.63 a\end{array}$ & $\begin{array}{c}50.31 \pm 7.61 b \\
47.81 \pm 9.42 \\
48.90 \pm 8.75 b\end{array}$ & $\begin{array}{c}49.57 \pm 8.27 b \\
48.38 \pm 9.70 \\
49.27 \pm 8.66 b\end{array}$ & $\begin{array}{c}50.03 \pm 7.54 b \\
50.46 \pm 9.21 \\
50.09 \pm 7.78 b\end{array}$ & $\begin{array}{c}<\mathbf{0 . 0 0 1} \\
0.318 \\
<\mathbf{0 . 0 0 1}\end{array}$ \\
\hline $\begin{array}{l}\text { Satisfaction with social support } \\
\qquad(15-75)^{\Psi}\end{array}$ & $\begin{array}{c}\text { Moças } \\
\text { Rapazes } \\
\text { Total }\end{array}$ & $\begin{array}{l}44.15 \pm 7.22 \\
45.13 \pm 7.28 \\
44.87 \pm 7.26\end{array}$ & $\begin{array}{l}45.90 \pm 7.21 \\
44.97 \pm 7.62 \\
45.38 \pm 7.45\end{array}$ & $\begin{array}{l}44.67 \pm 7.43 \\
46.09 \pm 7.01 \\
45.02 \pm 7.35\end{array}$ & $\begin{array}{l}45.50 \pm 6.99 \\
47.25 \pm 6.78 \\
45.74 \pm 6.98\end{array}$ & $\begin{array}{l}0.161 \\
0.205 \\
0.470\end{array}$ \\
\hline
\end{tabular}

Note: ${ }^{\Psi}$ Minimum and maximum scores of the scales, $a, b, c-$ means followed by different letters on the same line showed significant differences ( $p<0.05$ ); SRH. Sexual and Reproductive Health.

\section{DISCUSSION}

Regular and effective use of contraceptive methods depends on a wide range of factors, which should be considered when developing policies and programs to promote SRH for young people. The university students who participated in this study have sexual and contraceptive behaviors consistent with the commonly observed in this population group ${ }^{(22-23)}$. Most are sexually active, often in a relationship, and use the pill or condom as the contraceptive method. The high rate of girls using hormonal contraception is due to its high efficacy and easiness of use, since women are in most cases responsible for choosing the contraceptive method. On the other hand, the method most used by boys is the condom, which is highly recommended given 
the spontaneous and often unplanned nature of sexual relations in this age group ${ }^{(24)}$. Non-user dependent contraceptive methods (vaginal ring and contraceptive patch) and long-term methods (contraceptive implant and intrauterine device) were hardly used by participants, despite their association with increased efficacy and continued use $\mathrm{e}^{(5)}$. Given their high efficacy, those methods are recommended for women of all ages, including adolescents and young people ${ }^{(4)}$. In the last study on contraceptive practices of Portuguese women ${ }^{(17)}$, there was also low use of non-user dependent contraceptive methods. However, compared to previous years, there is an upward trend in the use of methods such as the vaginal ring $(2.7 \%)$, birth control implant $(5.4 \%)$, contraceptive patch $(3 \%)$ and IUD $(11.8 \%)$. In $34 \%$ of the cases, poor adherence to the pill was the reason for switching to another method, especially among younger age groups, since $29.4 \%$ of women between the ages of 20 and 29 reported forgetting to take the pill at least once in all cycles.

Dual protection has been recognized as a very safe strategy not only for preventing pregnancy, but also to provide protection against STDs, so its use, particularly by young people, is highly recommended ${ }^{(5,17,24)}$. The target sample of the present study does not reflect this behavior tendency, since there are two factors that determine the abandonment of condom: older age and sexual relations in the context of a relationship. Older students have the most inconsistent contraceptive behavior. The abandonment of the condom may be a result of the alleged reduction of sexual pleasure ${ }^{(7)}$, the hedonic personality, more marked in older boys ${ }^{(25)}$, and low perceptions of risk of acquiring an STD ${ }^{(10)}$. The influence of stable relationships on contraceptive choices and on the reduction of consistent use of condoms has been widely identified in young people ${ }^{(8,26)}$. On the perspective of pregnancy prevention, this might be a smart attitude. However, on the perspective of STD prevention this decision is based on strong trust in the partner's sexual past and monogamy. However, many sexual partners lie about their sexual past and there are high rates of unrevealed casual sex even in serious relationships, which in this study were reported by $26.1 \%$ of students.

A relatively recent study on contraceptive practices of Portuguese women ${ }^{(17)}$ found that the use of EC among general population is increasing $(17 \%)$, which has led to wide debate on the use of EC as a regular contraceptive method when it should be used only in exceptional circumstances. In the present study, the rate of EC use is the same as the above-mentioned national mean, which is about ten times higher than the mean found in similar studies also with university students ${ }^{(22)}$. The disparity between results points to a greater use of EC. In a study carried out in Spain, the majority of EC users are university students aged between 21 and 24, who associate the use of this method with condom rupture ${ }^{(27)}$. In the context of contraceptive counseling, guidance on how to use EC is recommended, since it is the last opportunity to avoid pregnancy after unprotected intercourse or failure of the regular method. This counseling should always convey the message that EC has no contraindications, but it has a contraceptive efficacy lower than any of the methods of regular contraception ${ }^{(5,28)}$. In that sense, the search for EC should be an opportunity for health professionals to promote the use of regular contraceptive methods appropriate to the needs of each young person ${ }^{(4)}$. Nursing professionals must be trained to meet specific demands of university students in order to ensure that they do not find barriers in the services that should support them and can find indications of contraceptives appropriate to their experience of sexuality or support for the use of $\mathrm{EC}^{(29)}$.

Although it was expected that higher education students would have high knowledge and skills in the field of contraception, the results of this study do not confirm this expectation, since about $7 \%$ of the girls and $33 \%$ of the boys indicated they had sex without using any type of contraception. This higher proportion among boys is commonly observed in university students ${ }^{(15)}$ and is usually justified by the greater value boys give to the hedonistic aspect of sex, seeking opportunities to have sex even if protection conditions are not met ${ }^{(30)}$. On the other hand, because the consequences of pregnancy affect young women more directly, they are inherently more prudent. The results indicate a positive association between greater knowledge and more favorable SRH attitudes and more protective behaviors. One of the findings of the present study that deserves some reflection is that students who do not use contraception are those with a more limited knowledge and a more unfavorable attitude. Knowledge has been pointed out as an important strategy to improve contraceptive practices ${ }^{(6,15)}$, so it has been the basis for contraceptive policies of several countries, including Portugal, where schools have been the main channel for the implementation of these policies ${ }^{(31)}$. Considering the postponement of the maturity of young adults, the hypothesis of continuing sex education in the university context must be considered. The form of transmission of this knowledge shouldn't be as formal as it is in secondary education, but should have training activities on contraception to promote the use of condoms, similar to those promoted by various public health entities linked to HIV/AIDS prevention. The efficacy of contraceptive methods may depend on other factors beyond knowledge, such as self-efficacy, peer influence, and social contexts. The results show that self-efficacy levels are higher in students who use contraception, which reflects the importance of this aspect for the use of condoms. Different studies have demonstrated this association ${ }^{(6,30)}$, noting that higher levels of self-efficacy are related not only to a more consistent use of condoms, but also to the ability to overcome barriers in acquiring them. Social support is considered in the literature as a protective factor of sexual risk behaviors among young people ${ }^{(21)}$. However, in the present study this aspect was not found to be important for the students' contraceptive choices.

\section{Study limitations}

It is possible to point the non-probabilistic sampling as a study limitation, since it can condition the generalization of the results. The self-reported measures of behavioral intention may also not be an accurate measure of actual behavior, and this type of data collection implies taking into account aspects such as social desirability and style of response.

Contributions to the area of nursing, health or public policy

Contraceptive education and prevention of STDs in young adults are not untimely and should be understood as health 
service priorities, since it is essential to focus on learning at the time when contraceptive routines are established in order to avoid discontinuation and prevent sexual risk behaviors. $\mathrm{SRH}$ policies should include the implementation of universal prevention campaigns for higher education students addressing topics such as responsible sexuality, contraception and safe sex practices. Sexual education strategies, in turn, should be complemented by the dissemination and availability of SRH services, which should appropriate to the real needs of this group and to both genders. Nurses, because of their proximity to the communities and the type of competencies they have, can play a fundamental role in the design and implementation of these strategies.

\section{CONCLUSION}

The results of the present study reflect the need to invest in the promotion of $\mathrm{SRH}$ among higher education students, considering a gender perspective. SRH promotion is essential to improve knowledge, attitude regarding contraceptive methods and condom use self-efficacy, factors that were associated with safer choices for contraceptives. The use of contraceptive methods is high, but contraceptive practices are primarily related with prevention of unintended pregnancies, with inconsistent condom use or even abandonment, particularly by older students involved in a relationship, which leaves students more vulnerable to STDs.

\section{REFERENCES}

1. Kann L, McManus T, Harris W, Shanklin SL, Flint K, Hawkins J, et al. Youth risk behavior surveillance - United States, 2015. CDC [Internet]. 2016 [cited 2017 Jul 06];65(6):1-171. Available from: http://doi.org/10.15585/mmwr.ss6506a1

2. Lazarus JV, Sihvonen-Riemenschneider H, Laukamm-Josten U, Wong F, Liljestrand J. Systematic review of interventions to prevent spread of sexually transmitted infections, including HIV, among young people in Europe. Croat Med J [Internet]. 2010 [cited 2017 Jul 06];51(1):74-84. Available from: http://doi.org/10.3325/cmj.2010.51.74

3. Neto S, Bombas T, Arriaga C, Almeida MC, Moleiro P. Contraceção na adolescência: recomendações para o aconselhamento contracetivo. Sociedade Portuguesa de Medicina do Adolescente da Sociedade Portuguesa de Pediatria; 2012.

4. Portugal. Direção-Geral da Saúde. Orientação nº 10/2015: Disponibilidade de métodos contracetivos. Lisboa: Autor; 2015.

5. Lopez LM, Otterness C, Chen M, Steiner M, Gallo MF. Behavioral interventions for improving condom use for dual protection. Cochrane Database Syst Rev [Internet]. 2013 [cited 2017 May 10];10. CDC 010662. Available from: http://doi.org/10.1002/14651858. CD010662.pub2

6. Kirby D, Coyle K, Alton F, Rolleri L, Robin L. Reducing adolescent sexual risk: theoretical guide for developing and adapting curriculum-based programs. California: ETR Associates; 2011.

7. Reis M, Matos MG. Contraceção em jovens universitários portugueses. Anál Psicol[Internet]. 2008 [cited 2017 May 10];26(1):71-9. Available from: http://aventurasocial.com/arquivo/1303594526_ANAL_PSI_2008.pdf

8. Gomes A, Nunes C. Caracterização do uso do preservativo em jovens adultos portugueses. Anál Psicol [Internet]. 2011 [cited 2017 May 10];4(29):489-503. Available from: http://www.scielo.mec.pt/pdf/aps/v29n4/v29n4a01.pdf

9. Associação para o Planeamento da Família. Direitos e saúde sexual e reprodutiva de jovens na Europa. Um guia para o desenvolvimento de políticas sobre direitos e saúde sexual e reprodutiva de jovens na Europa. Lisboa: APF; 2010.

10. O'Sullivan LF, Udell W, Montrose VA, Antoniello P, Hoffman S. A Cognitive analysis of college students' explanations for engaging in unprotected sexual intercourse. Arch Sex Behav [Internet]. 2010 [cited 2017 Jul 06];39(5):1121-31. Available from: http://doi. org/10.1007/s10508-009-9493-7

11. Ssewanyana D, Sebena S, Petkeviciene J, Lukács A, Miovsky M, Stock C. Condom use in the context of romantic relationships: a study among university students from 12 universities in 4 Central and Eastern European countries. Eur J Contracep Repr [Internet]. 2015 [cited 2017 Jul 06];9:1-11. Available from: http://dx.doi.org/10.3109/13625187.2014.100102415

12. Wicki M, Kuntsche E, Gmel G. Drinking at European universities? A review of students' alcohol use. Addict Behav [Internet]. 2010[cited 2017 Jul 06];35(11):913-24. Available from: https://www.ncbi.nlm.nih.gov/pubmed/20624671

13. Rodrigues P, Salvador A, Lourenço I, Santos, L. Padrões de consumo de álcool em estudantes da Universidade de Aveiro: relação com comportamentos de risco e stresse. Anál Psicol[Internet]. 2014 [cited 2017 May 10];4(32):453-66. Available from: http:// dx.doi.org/1014417/ap.32.3.789

14. Kuperberg A, Padgett JE. Dating and hooking up in college: meeting contexts, sex, and variation by gender, partner's gender, and class standing. J Sex Res [Internet]. 2015 [cited 2017 Jul 06];52(5):517-31. Available from: https://www.ncbi.nlm.nih.gov/ pubmed/24750129

15. Reis M, Ramiro L, Matos MG, Diniz, JA. Determinants influencing male condom use among university students in Portugal. Int J Sex Health [Internet]. 2013[cited 2017 Jul 06];25(2):115-27. Available from: http://dx.doi.org/10.1080/19317611.2012.728554

16. Uecker JE. Social context and sexual intercourse among first-year students at selective colleges and universities in the United States. Social Science Research [Internet]. 2015 [cited 2017 May 10];52:59-71. Available from: http://dx.doi.org/10.1016/j. ssresearch.2015.01.005 
17. Sociedade Portuguesa de Ginecologia e Sociedade Portuguesa da Contraceção. Estudo das práticas contracetivas das mulheres portuguesas. Lisboa: Autor; 2015.

18. Ott MA, Sucato GS, Committee on Adolescence. contraception for adolescents. Pediatr[Internet]. 2014 [cited 2017 May 08];134(4):1257-81. Available from: http://dx.doi.org/10.1542/peds.20142300

19. Brien TM, Thombs DL, Mahoney CA, Wallnau L. Dimensions of self-efficacy among three distinct groups of condom users. J Am Coll Health [Internet]. 1994 [cited 2017 May 08];42(4):167-74. Available from: https://doi.org/10.1080/07448481.1994.9939665

20. Santos MJ, Ferreira E, Duarte J, Ferreira M. Portuguese adaptation and validation of the brief version of Condom Use Self-efficacy Scale in college students. Rev Int Androl [Internet]. 2016 [cited 2017 Jul 06];15(1):23-30. Available from: https://doi.org/10.1016./j. androl.2016.06.002

21. Ribeiro JLP. Escala de satisfação com o suporte social. Anál Psicol[Internet]. 1999 [cited 2017 Jul 06]; 17(3), 547-58. Available from: http://www.scielo.mec.pt/pdf/aps/v17n3/v17n3a10.pdf

22. Reis M, Ramiro R, Matos MG, Diniz J. Os comportamentos sexuais dos universitários portugueses de ambos os sexos em 2010. Rev Port Saúde Pública [Internet]. 2011 [cited 2017 Jul 06];30(2):105-14. Available from: https://doi.org/10.1016/j.rpsp.2012.12.001

23. Alves AS, Lopes MHM. Uso de métodos anticoncepcionais entre adolescentes universitários. Rev Bras Enferm [Internet]. 2008 [cited 2017 Jul 16];61(2):170-77. Available from: http://dx.doi.org/10.1590/S0034-71672008000200005

24. Tyler CP, Whiteman MK, Kraft J, Zapata L, Hillis S, Curtis K, et al. Dual use of condoms with other contraceptive methods among adolescents and young women in the United States. J Adolescent Health [Internet]. 2014 [cited 2017 Jul 06];54(2):169-75. Available from: https://doi.org/10.1016/j.jadohealth.2013.07.042

25. Voisin D, King K, Schneider J, Diclemente R, Tan K. Sexual sensation seeking, drug use and risky sex among detained youth. AIDS Clin Res [Internet]. 2012 [cited 2017 Jul 06];S1:1-5. Available from: https://doi.org/10.4172/2155-6113.S1-017

26. Delatorre MZ, Dias ACG. Conhecimentos e práticas sobre métodos contraceptivos em estudantes universitários. Rev SPAGESP [Internet]. 2015 [cited 201716 Jul];16(1):60-73. Available from: http://pepsic.bvsalud.org/pdf/rspagesp/v16n1/v16n1a06.pdf

27. Amengual MLB, Canto ME, Berenguer IP, Pol MI. Revisão sistemática do perfil de usuárias de contracepção de emergência. Rev Latino-Am Enfermagem [Internet]. 2016 [cited 2017 Jul 06];24:e2733. Available from: http://dx.doi.org/10.14295/idonline.v11i35.736

28. International Consortium for Emergency Contraception. Repeated use of emergency contraceptive pills: the facts [Internet]. New York: ICEC: 2015[cited 2017 Jul 06]. Available from: http://www.cecinfo.org/custom-content/uploads/2015/10/ICEC RepeatUse_Oct-2015.pdf.

29. Moscou S. Meeting contraceptive needs of college students: Bringing evidence into practice. J Nurse Practitioners [Internet]. 2016 [cited 2017 Jul 06];12(1):e11-e15. Available from: https://doi.org/10.1016/j.nurpra.2015.09.013.

30. Asare M. Using the theory of planned behavior to determine the condom use behavior among college students. Am J Health Stud [Internet]. 2015 [cited 2017 Jul 06];30(1):43-50. Available from: https://www.ncbi.nlm.nih.gov/pmc/articles/PMC4621079/

31. Rocha AC, Duarte C. Impacto das políticas públicas na promoção da educação sexual: o caso português. Glob J Comm Psych Practice [Internet]. 2016[cited 201716 Jul];7(1s):1-23. Available from: http://www.gjcpp.org/pdfs/Porto4 12016\%20lmpacto\%20 das $\% 20$ Pol_ticas $\% 20$ P_blicas_FINAL-FORMATTED.pdf 